\title{
Faktor-faktor yang mempengaruhi masyarakat muslim Kabupaten Semarang
}

\author{
Septia Ayum Pratiwi ${ }^{1}$ Abdul Aziz Nugraha Pratama ${ }^{1 *}$ \\ ${ }^{1}$ Fakultas Ekonomi dan Bisnis Islam IAIN Salatiga, Indonesia \\ ${ }^{*}$ Korespondensi (e-mail: pratama abdul@yahoo.com)
}

\begin{abstract}
This study aims to determine the effect of religiosity, income, and family members on people's welfare with consumption pattems as an intervening variable in Muslim communities in Semarang Regency. The research method is descriptive quantitative with 100 samples from Muslim residents in Semarang Regency based on questionnaire answers and processed using multiple linear analysis methods. The results show that religiosity and consumption pattems positively and significantly affect welfare. Meanwhile, income and the number of family members do not affect welfare. Simultaneously, the variables of religiosity, revenue, number of family members, and consumption patterns have a positive and significant effect on welfare. Path analysis concluded that consumption patterns could mediate the influence of religiosity, income, number of family members on the welfare of the Muslim community in Semarang Regency.
\end{abstract}

Keywords: Religiosity, Income, Number of Family, Consump tion Patterns, Welfare

\begin{abstract}
Abstrak
Penelitian ini bertujuan untuk mengetahui pengaruh religiusitas, pendapatan, dan jumlah anggota keluarga terhadap kesejahteraan masyarakat dengan pola konsumsi sebagai variabel intervening pada masyarakat Muslim di Kabupaten Semarang. Metode pengumpulan data dengan kuesioner yang diberikan kepada masyarakat beragama Islam di Kabupaten Semarang yang telah berkeluarga dan berpendapatan sebanyak 100 responden dengan menggunakan teknik random sampling dan diolah menggunakan metode analisis regresi linear berganda. Hasil penelitian ini, menunjukkan bahwa secara positif dan signifikan religiusitas dan pola konsumsi memberi pengaruh terhadap kesejahteraan. Sedangkan pendapatan dan jumlah anggota keluarga tidak memberi pengaruh terhadap kesejahteraan mayarakat. Secara simultan variabel religiusitas, pendapatan, jumlah anggota keluarga, dan pola konsumsi berpengaruh positif dan signifikan terhadap kesejahteraan. Melalui analisis jalur, dapat dikemukakan bahwa pola konsumsi mampu memedias pengaruh religiusitas, pendapatan, jumlah anggota keluarga terhadap kesejahteraan masyarakat Muslim di Kabupaten Semarang
\end{abstract}

Kata kunci: Religiustias, Pendapatan, Jumlah Anggota Keluarga, Kejahteraan, Pola Konsumsi

How to cite: Pratiwi, S. A., \& Pratama, A. A. N. (2021). Faktor-faktor yang mempengaruhi kesejahteraan masyarakat muslim Kabupaten Semarang. Journal of Economics Research and Policy Studies, 1(2), 91-105. https://doi.org/10.53088/jerps.v1i2.105

\section{Pendahuluan}

Kesejahteraan akan selalu diharapkan oleh seluruh masyarakat. Kesejahteraan dapat menimbulkan rasa nyaman, aman, dan keleluasaan dalam menjalani kehidupan sehari-hari. Dalam Islam, kesejahteraan merupakan suatu tujuan. Allah 
memberikan kesejahteraan jika manusia menjalankan segala yang diperintahkan dan meninggalkan yang dilarang agama. Dengan demikian, kesejahteraan bukan hanya berdasar pada material namun dilihat pula sisi spiritual dan moral.

Kesejahteraan tidak terlepas dari adanya pertumbuhan ekonomi. Kesejahteraan yang hakiki ada dikarenakan singkronisasi antara petumbuhan ekonomi dan distribusi. Pertumbuhan terhadap ekonomi ini tentunya memerlukan beberapa faktor pendorong berupa kegiatan konsumsi. Dalam mengonsumsi suatu barang maupun jasa, manusia akan menyesuaikan dengan pola pikir dan pendapatan yang didapatnya (Beik \& Arsyianti, 2016). Islam memberikan batasan-batasan konsumsi tidak terbatas berdasarkan halal haram saja, melainkan dilihat dari efek baik buruknya, kecocokannya, kehigienisan, dan terhindar dari kemewahan yang akan mengakibatkan kesombongan. Batasan ini tidak hanya berlaku pada konsumsi makan minum saja, akan tetapi juga mecakup berbagai komoditi lain. Komoditas yang kiranya memiliki zat berbahaya terhadap moral dan spiritual juga diharamkan. Oleh karena itu, pengeluaran konsumsi yang baik tidak hanya untuk dunia, melainkan juga untuk akhirat kelak (Ma'zumi, 2017).

Keyakinan yang mendalam akan suatu agama pada manusia terbentuk dengan adanya tradisi kepercayaan yang ada. Religiusitas akan memengaruhi pola pikir, indra perasa, dan cara pandang manusia untuk melihat nilai agamanya. Hal ini berarti religiusitas berfungsi sebagai kekuatan yang mampu menstabilkan masyarakat maupun individu (Zakariya, 2018). Seorang yang beagama Islam memiliki kereligiusan akan mencoba melakukan ajaran Islam secara keseluruhan. Tingkatan pengetahuan beragama yang dimiliki setiap orang juga berbeda bergantung bagaimaan cara orang tersebut meyakini dan mengamalkan ajaran agamanya. Perbedaan tingkat ketakwaan pada manusia itulah disinyalir menjadi salah satu penyebab perbedaan perilaku konsumsi (Pratama \& Yudiana, 2020).

Dalam penelitian yang ditulis oleh Rois, dijelaskan bahwa religiusitas berpengaruh positif dan signifikan tehadap keinginan seseorang untuk mengkonsumsi suatu produk makanan ringan yang memiliki label halal. Selain itu, penelitian Desi Fatmawati pada tahun 2015 menyatakan bahwa religiusitas memiliki pengaruh terhadap keinginan konsumsi. Dengan demikian tingkat keyakinan beragama yang dimiliki seseorang akan berpengaruh terhadap keinginan untuk mengkonsumsi barang. Aprilia dalam tesisnya pada tahun 2018 menjelaskan bahwa, dalam memenuhi kebutuhannya, individu maupun rumah tangga diharuskan memiliki pendapatan.

Pendapatan merupakan sejumlah uang yang diberikan kepada pekerja dikarenakan telah melakukan suatu pekerjaan yang ada dan diberikan pada waktu tertentu sesuai dengan kesepakatan. Besar kecilnya pembelanjaan untuk konsumsi dapat mem berikan gambaran seberapa besarkah tingkat kesejahteraan suatu rumah tangga (Hanum, 2017). Nurlaila Hanum dalam penelitianya tahun 2017 menyebutkan bahwa pendapatan yang diterima oleh setiap individu berpengaruh terhadap perilaku konsumsi mahasiswa. Pernyataan ini sejalan dengan penelitian (Vidiawan \& Tisnawati, 2015) yang menyatakan bahwa penghasilan memiliki pengaruh besar 
kepada bagaimana rumah tangga mengatur pembelanjaan untuk menonsumsi barang dan jasa.

Pada tahun 2018, Refky Fielnanda dan Nur Sahara telah melakukan penelitian bagaimana jumlah tanggungan dalam keluarga memberi pengaruh kepada belanja keluarga. Hasil penelitian tersebut menunjukkan jika benar terdapat hubungan antara jumlah tanggungan tersebut dalam besar kecilnya belanja keluarga. Hal yang sama juga dikemukakan dalam karya Eka Vidiawan serta Ni Made Trisnawati pada tahun 2015. Namun penelitian berbeda dilakukan oleh Dyah Umiyarni dkk pada tahun 2016 yang menghasilkan kesimpulan mengenai jumlah anggota keluarga tidak memiliki pengaruh dengan konsumsi maupun kesejahteraan. Hal yang sama bahkan berbeda dapat pula terjadi di daerah dalam hal ini Kabupaten Semarang yang secara geografi terbagi ke dalam 19 Kecamatan yang memiliki sector perekonomian masing-masing dan tingkat kesejahteraan penduduk yang masih berbeda di setiap wilayahnya sehingga sangat menarik untuk dilakukan penelitian.

\section{Metode Penelitian}

Untuk menyusun penelitian ini dilakukan pendekatan secara kuantitatif deskriptif dengan mengkaji data primer guna mendapatkan informasi terkini dari masyarakat langsung. Metode ini berdasarkan pada data primer yang telah dikumpulkan secara kolektif berisi kenyataan dan karakteristik objek penelitian dengan mengaitkan variable bebas $(\mathrm{X})$, terikat $(\mathrm{Y})$, dan mediasi $(\mathrm{Z})$.

Metode tersebut bertujuan untuk menggabarkan dan menjelaskan permasalahan yang ada dalam penelitian ini. Metode survey dilakukan sebagai cara untuk menemukan kejadian yang relatif pada populasi kecil maupun besar. (Nuriyanto et al., 2019)

Berikut merupakan model penelitian dalam penelitiani ini:

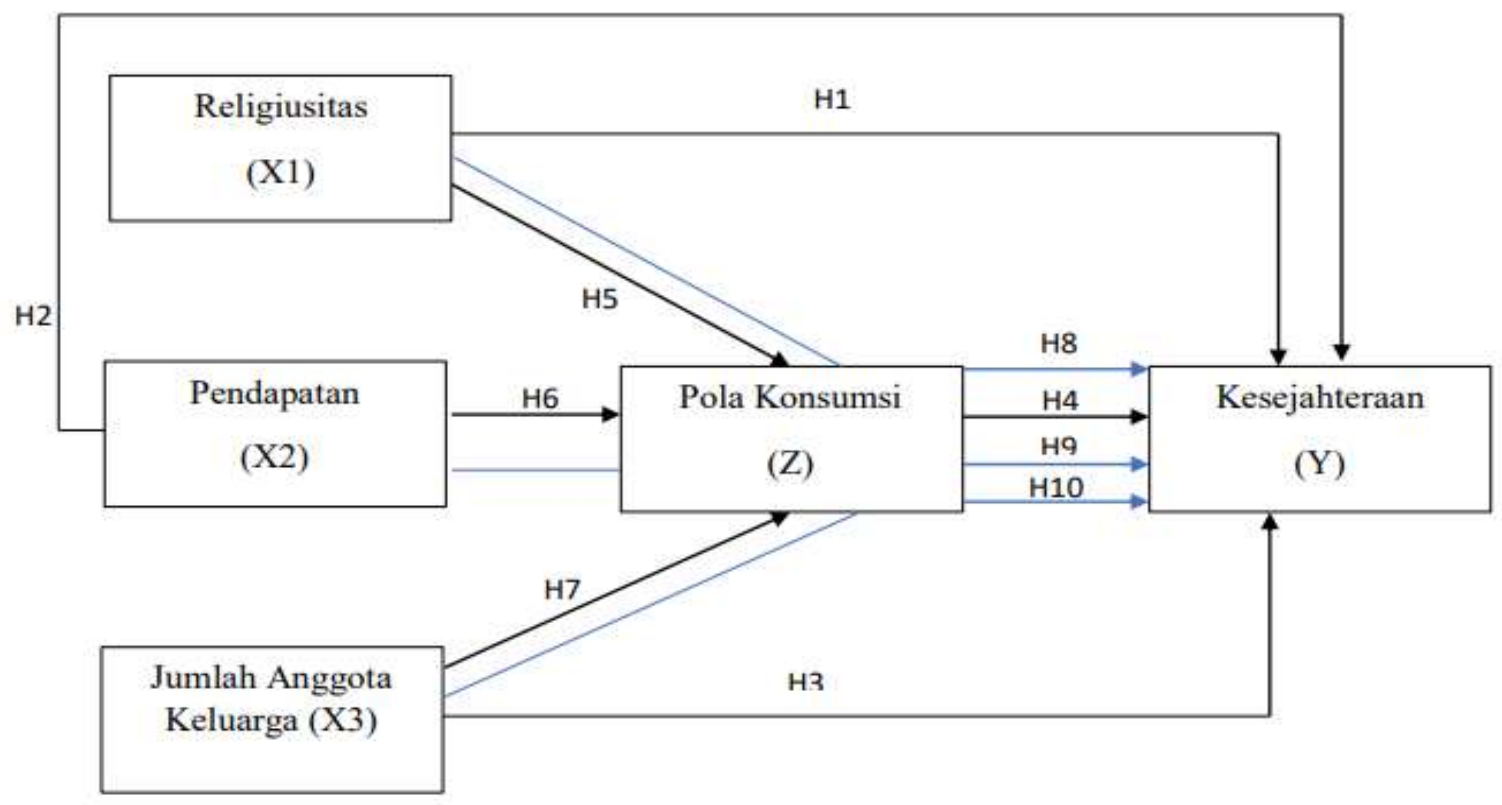

Gambar 1. Model Penelitian dan Hipotesis 
Untuk membuktikan seluruh hipotesis selanjutnya akan dilakukan uji asumsi klasik meliputi uji nomalitas, multikoleniaritas, dan heteroskedastisitas. Uji berikutnya yakni uji determinasi $\mathrm{R}^{2}$, uji F simultan, uji T, dan uji path analysis.

\section{Hasil dan Pembahasan}

\subsection{Hasil penelitian}

\section{Uji Normalitas}

Baiknya dalam sebuah penelitian, populasi data harus bedistribusi nomal. Ketika diketahui nilai probabilitas lebih besar dari nilai signifikansi 0,05 maka data berdistribusi nomal. Untuk melakukan uji ini dapat dilakukan dengan uji nonprametik Kolmogorov Smirnov (Ghozali, 2016).

\begin{tabular}{lr} 
Tabel 1. Uji Normalitas Kolmogorov-Smirnov \\
\hline & $\begin{array}{c}\text { Unstandardized } \\
\text { Residual }\end{array}$ \\
\hline Kolmogorov-Smirnov Z & 1,086 \\
Asymptotic Significance (2-tailed) & 0,189 \\
\hline
\end{tabular}

Berdasar hasil uji tersebut dapat diketahui bahwa nilai Asymptotic Significance adalah sebesar 0,187>0,05 yang berarti data berdistribusi normal.

\section{Uji Multikoleniaritas}

Uji multikolinearitas dilakukan untuk mengetahui ada tidaknya hubungan yang sangat kuat antara variabel bebas. Variable bebas haruslah terbebas dan tidak berkaitan satu sama lain atau jika tidak maka hubungan antara variable bebas dan terikat akan mengalami gangguan (Ghozali, 2016).

Tabel 2. Uji Multikolenieritas

\begin{tabular}{lrrrr}
\hline Model & Coefficients & Std. Error & Tolerance VIF \\
\hline Religiusitas & 0,396 & 0,083 & 0,235 & 4,258 \\
Pendapatan & $-0,039$ & 0,095 & 0,947 & 1,056 \\
Jumlah Anggota Keluarga & $-0,148$ & 0,115 & 0,130 & 7,668 \\
Pola Konsumsi & 0,429 & 0,135 & 0,207 & 4,827 \\
\hline
\end{tabular}

Berdasar pada Tabel 2 dapat diketahui bahwa seluruh nilai tolerance lebih dari 0,10 dan VIF lebih kecil dari 10 yang artinya tidak ditemukan gejala multikoleniaritas dalam data.

\section{Uji Heteroskedastisitas}

Uji ini dilakukan untuk mengetahui apakah terdapat varian yang berbeda dari residual satu dengan yang lainnya. Sedangkan regresi yang baik ialah yang bersifat homogen dan tetap. Metode yang dapat digunakan ialah uji glejser (Bawono, 2006). Berdasarkan hasil olah data, dapat dilihat bahwa nilai significant seluruh variable bernilai lebih besar dari 0,05 sehingga dalam data tidak ditemukan gejala heterosekdastisitas. 
Tabel 3. Uji Heteroskedastisitas

\begin{tabular}{lrrrr}
\hline \multicolumn{1}{c}{ Model } & \multicolumn{1}{c}{ B } & Std. Error & \multicolumn{1}{c}{$\mathrm{t}$} & Significance \\
\hline (Constant) & 2,386 & 0,763 & 3,127 & 0,002 \\
Religiusitas & $-0,076$ & 0,053 & $-1,440$ & 0,153 \\
Pendapatan & 0,045 & 0,061 & 0,747 & 0,457 \\
Jumlah Anggota Keluarga & $-0,043$ & 0,073 & $-0,580$ & 0,563 \\
Pola Konsum si & 0,031 & 0,086 & 0,357 & 0,722 \\
\hline
\end{tabular}

\section{Uji Koefisien Determinasi $\left(R^{2}\right)$}

Uji koefisien deteminasi atau $\left(R^{2}\right)$ adalah uji untuk mengetahui sejauh mana ketepatan garis regresi atau model regresi yang terbentuk dalam mewakili kelom pok hasil data pengamatan (Bawono \& Shina, 2018). Jadi uji koefisien determinasi digunakan untuk melihat sejauh mana kontribusi pengaruh variabel independen terhadap variabel dependen. Besar nilai koefisien deteminasi adalah antara 0 dan 1. Semakin nilai $\mathrm{R}^{2}$ mendekati 1 , maka ketepatan dikatakan semakin baik (Bawono \& Shina, 2018).

Tabel 4. Hasil Uji R2

\begin{tabular}{lrrrr}
\hline Model & $\mathrm{R}$ & $\mathrm{R}$ Square & $\begin{array}{c}\text { Adjusted } \mathrm{R} \\
\text { Square }\end{array}$ & $\begin{array}{c}\text { Std. Error of the } \\
\text { Estimate }\end{array}$ \\
\hline 1 & $0,792^{\mathrm{a}}$ & 0,27 & 0,611 & 0,81946 \\
\hline
\end{tabular}

Nilai koefisien korelasi (R) adalah sebesar 0,792 maka dapat disimpulkan bahwa nilai $\mathrm{R}$ mendekati angka 1 . Sehingga dapat disimpulkan terdapat hubungan yang kuat antar variable independen dengan variabel dependen. Nilai koefisien determinasi $\left(R^{2}\right)$ adalah sebesar 0,611 yang dapat diartikan bahwa variabel independen memberikan kontribusi pengaruh terhadap variabel dependen sebesar $61,1 \%$ sedangkan $38,9 \%$ dipengaruhi oleh variabel lain yang tidak termasuk dalam penelitian ini.

\section{Uji F Simultan}

Uji $F$ adalah uji untuk mengetahui apakah semua variabel independen secara serentak memiliki pengaruh terhadap variabel dependen. Berdasarkan Tabel 5 dapat dlihat bahwa nilai sig kurang dari 0,05 sehingga daapt disimpulkan bahwa religiusitas, pendapatan, jumlah anggota keluarga, dan pola konsumsi secara bersama-sama mempengaruhi kesejahteraan masyarakat.

Tabel 5. Hasil Uji F

\begin{tabular}{lccccc}
\hline Model & $\begin{array}{c}\text { Sum of } \\
\text { Squares }\end{array}$ & df & $\begin{array}{c}\text { Mean } \\
\text { Square }\end{array}$ & F & $\begin{array}{c}\text { Significanc } \\
\mathrm{e}\end{array}$ \\
\hline $1 \quad$ Regression & 107.196 & 4 & 26.799 & 39.908 & $.000^{\mathrm{b}}$ \\
\hline $\begin{array}{l}\text { a. Dependent Variable:Y Kesejahteraan } \\
\text { b. Predictors: (constant)Z Pola Konsumsi, X2 }\end{array}$ \\
Anggota Keluarga...
\end{tabular}

\section{Uji validitas pengaruh (uji t)}

Variabel dependen ZPola konsumsi Z 
Uji ini dilakukan untuk mengetahui hubungan antara variabel independen terhadap variabel mediasi.

Tabel 6. Hasil Uji t terhadap Z

\begin{tabular}{lrrrr}
\hline \multicolumn{1}{c}{ Model } & Coefficients & Std. Error & \multicolumn{1}{c}{$\mathrm{t}$} & Significance \\
\hline (Constant) & $-1,185$ & 0,899 & $-1,318$ & 0,191 \\
X1 Religiusitas & 0,041 & 0,063 & 0,650 & 0,517 \\
X2 Pendapatan & $-0,132$ & 0,071 & $-1,867$ & 0,065 \\
X3 Jumlah Anggota Keluarga & 0,572 & 0,065 & 8,814 & 0,000 \\
\hline
\end{tabular}

Pada Tabel 6 dapat diketahui bahwa religiusitas memiliki nilai sig 0,517>0,05 dan pendapatan sebesar $0,065>0,05$ sehingga tidak berpengaruh terhadap pola konsumsi. Sedangkan variabel jumlah anggota keluarga bemilai sig 0,00<0,05 yang berarti dapat memengaruhi pola konsumsi secara positif dan signifikan.

\section{Variabel dependen Y Kesejahteraan}

Uji ini dilakukan untuk mengetahui hubungan antara variabel independen dan variabel mediasi terhadap variabel dependen.

Tabel 7. Hasil uji t terhadap varabel $Y$

\begin{tabular}{lrrrr}
\hline \multicolumn{1}{c}{ Model } & Coefficients & Std. Error & \multicolumn{1}{c}{$\mathrm{t}$} & Significance \\
\hline (Constant) & 3,815 & 1,199 & 3,182 & 0,002 \\
X1 Religiusitas & 0,396 & 0,083 & 4,750 & 0,000 \\
X2 Pendapatan & $-0,039$ & 0,095 & $-0,405$ & 0,686 \\
X3 Jumlah Anggota Keluarga & $-0,148$ & 0,115 & $-1,284$ & 0,202 \\
Z Pola Konsumsi & 0,429 & 0,135 & 3,178 & 0,002 \\
\hline
\end{tabular}

Berdasarkan Tabel 7 tersebut dapat dilihat bahwa nilai sig variabel religiusitas dan pola konsumsi bernilai kurang dari 0,05 sehingga berpengaruh positif dan signifikan terhadap kesejhateraan. Sedangkan variabel pendapatan dan jumlah anggota keluarga bernilai lebih besar dari 0,05 sehingga tidak memiliki pengaruh terhadap kesejahteraan.

\section{Uji Path Analysis}

Uji ini dilakukan untuk menguji seberapa besar kemampuan variable mediasi dalam memengaruhi hubungan antara variable bebas dan variable terikat. Uji ini disebut juga dengan analisis jalur sebagai perluasan dari regresi linear berganda (Ghozali, 2016). Persamaan regresi untuk menghitung pengaruh religiusitas (X1), pendapatan (X2), dan jumlah anggota keluarga (X3) terhadap kesejahteraan (Y) dengan pola konsumsi (Z) sebagai variabel intervening dengan menggunakan analisis jalur adalah sebagai berikut:

$$
\begin{aligned}
& Y=ß 0+ß 1 X 1+\beta 2 X 2+\beta 3 X 3+e 1 \ldots \ldots \ldots . . . \\
& Y=ß 0+ß 1 X 1+\beta 2 X 2+\beta 3 X 3+ß 4 Z+e 2 .
\end{aligned}
$$

Keterangan:
$\mathrm{X} 1$ : religiusitas
Y: kesejahteraan
$\mathrm{X} 2$ : pendapatan
$\mathrm{e} 1: \mathrm{v}\left(1-\mathrm{R}^{2}\right)$
X3: jumlah anggota keluarga
$\mathrm{e} 2 \mathrm{v}\left(1-\mathrm{R}^{2}\right)$ 
Pada persamaan (1) digunakan untuk menganalisis penganuh religiusitas, pendapatan dan jumlah anggota keluarga terhadap pola konsumsi. Kemudian persamaan (2) digunakan untuk menganalisis pengaruh variabel pengaruh religiusitas, pendapatan dan jumlah anggota keluarga terhadap kesejahteraan.

Dari Tabel 6 hasil uji t terhadap variable mediasi $(Z)$ dapat diperoleh model pada persamaan 1 yaitu $Y=-1,185+0,041 X 1+(-0,132) X 2+0,572 X 3+\varepsilon 1$. Dari tabel 7 hasil uji t terhadap variable dependen $(Y)$ dapat diperoleh model pada persamaan 2 yaitu $Y=3,815+0,396 X 1+(-0,039) X 2+(-0,148) X 3+0,429(Z)+\varepsilon 2$ sehingga dapat dsm pulkan dalam model analisis jalur sebaga berikut:

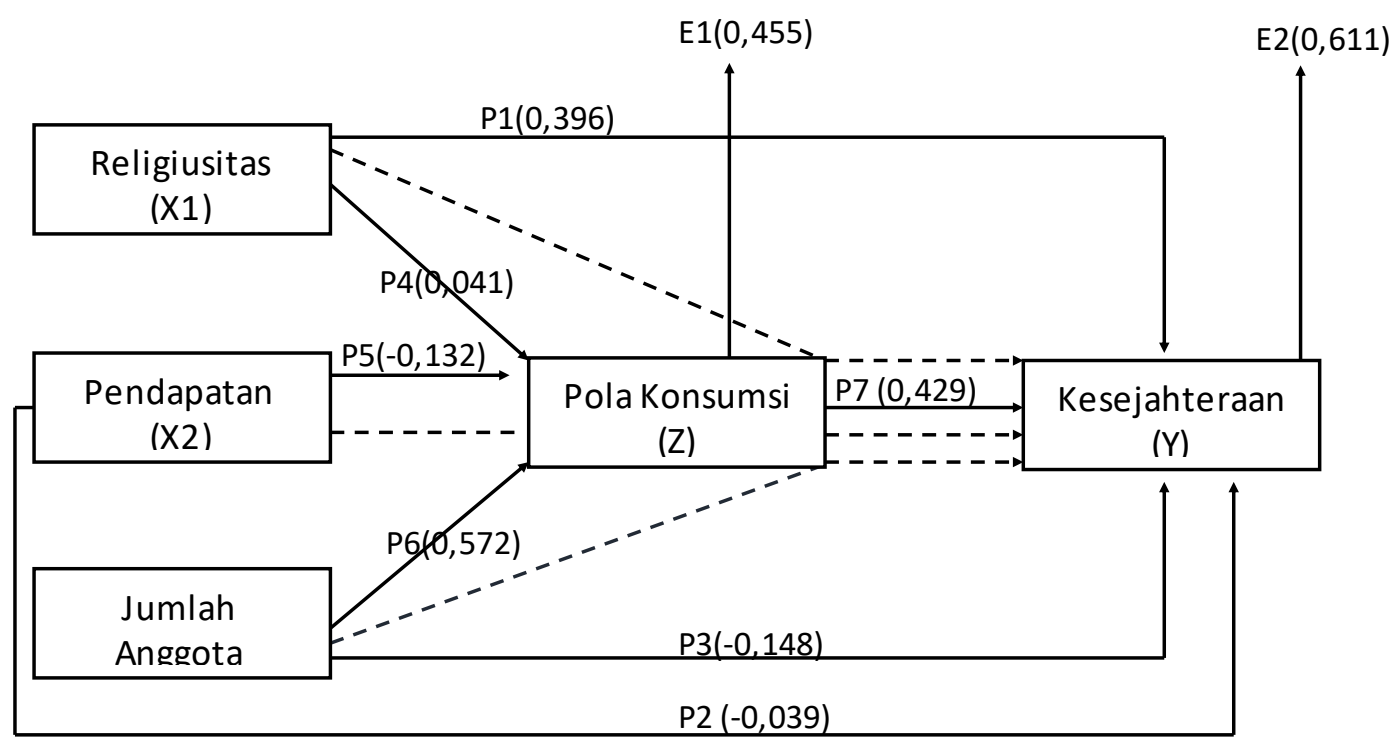

Gambar 2. Model Path Analysis

\section{Pengaruh religiusitas (X1) terhadap kesejahteraan (Y) melalui pola konsumsi} (Z)

Pengaruh langsung variabel religiusitas terhadap kesejahteraan (P1) adalah 0,396 kemudian untuk pengaruh tidak langsung variabel religiusitas terhadap kesejahteraan melalui pola konsumsi adalah $(P 4 \times P 7)=(0,041 \times 0,429)=0,017$. Sedangkan untuk total pengaruh langsung dan tidak langsung religiusitas terhadap kesejahteraan adalah $\mathrm{P} 1+(\mathrm{P} 4 \times \mathrm{P} 7)=0,396+(0,041 \times 0,429)=0,413$. Untuk mengetahui pengaruh mediasinya, maka digunakan sobel test sebagai berikut:

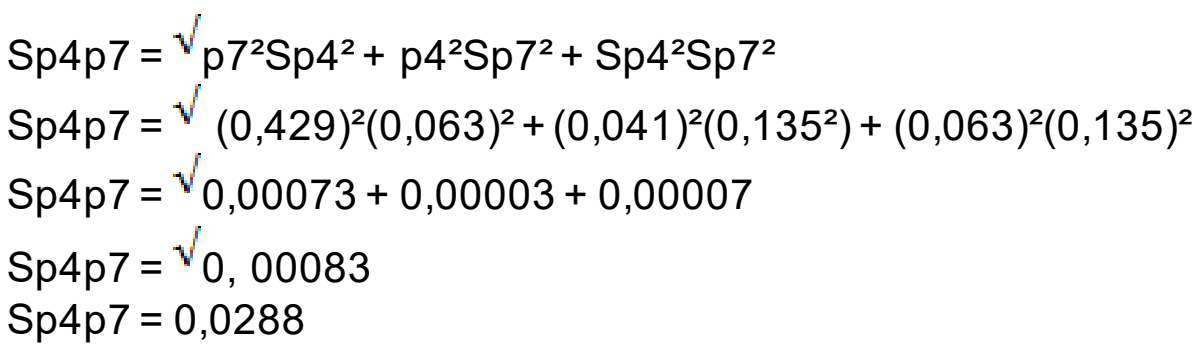

Keterangan:

P4: Koefisien variabel bebas

P7: koefisien Variabel mediasi 
Sp4: Standar error koefisien 1

Sp7: standar error koefisien 2

Berdasarkan Sp4p7 dapat dihitung nilai t statistik pengaruh mediasi dengan rumus:

$$
\begin{aligned}
& \mathrm{t}=\mathrm{p} 4 \mathrm{p} 7: \mathrm{Sp} 4 \mathrm{p} 7 \\
& =0,0175: 0,0288 \\
& =0,667
\end{aligned}
$$

Dari nilai thitung diatas yaitu sebesar 0,667 lebih besar dari t tabel senilai 1,66055 dengan signifikansi $5 \%$ atau 0,05 . Sehingga dapat disimpulkan bahwa ada pengaruh mediasi dari pola konsumsi pada variabel religiusitas terhadap kesejahteraan.

Pengaruh pendapatan (X2) terhadap kesejahteraan (Y) melalui pola konsumsi (Z)

Pengaruh langsung variabel pendapatan terhadap kesejahteraan (P2) adalah 0,039 kem udian untuk pengaruh tidak langsung antara variabel pendapatan terhadap kesejahteraan melalui pola konsumsi adalah $(P 5 \times P 7)=(0,132 \times 0,429)=0,0566$. Sedangkan untuk pengaruh langsung dan tidak langsung dari variabel pendapatan terhadap kesejahteraan adalah P2 $+(\mathrm{P} 5 \times \mathrm{P} 7)=0,039+(0,132 \times 0,429)=0,0956$. Untuk mengetahui pengaruh mediasinya, maka digunakan sobel test sebagai berikut:

$$
\begin{aligned}
& \text { Sp5p7 }=\sqrt{ } \mathbb{V}^{2} S p 5^{2}+p 5^{2} S p 7^{2}+S p 5^{2} S p 7^{2} \\
& \text { Sp5p7 }=\sqrt{ }(0,429)^{2}(0,071)^{2}+(0,132)^{2}\left(0,135^{2}\right)+(0,095)^{2}(0,135)^{2} \\
& \text { Sp5p7 }=\sqrt{ } 0,00092+0,00032+0,00016 \\
& \text { Sp5p7 }=\sqrt{ }_{0,0014}=0,0374 \\
& \text { Keterangan: }
\end{aligned}
$$

P5: Koefisien variabel bebas

P7: Koefisien variabel mediasi

Sp5: Standar error koefisien 1

Sp7: Standar error koefisien 2

Berdasarkan Sp5p7 dapat dihitung t statistik dengan rumus sebagai berikut:

$$
\begin{aligned}
& \mathrm{t}=\mathrm{P} 2 \mathrm{P} 7: \mathrm{Sp} 2 \mathrm{p} 7 \\
& =0,01677: 0,03728=0,44983
\end{aligned}
$$

Dari nilai $t$ hitung diatas yaitu sebesar 0,44983 lebih kecil dari $t$ tabel 1,66055 dengan signifikansi $5 \%$. Maka dapat diambil kesimpulan bahwa tidak ada pengaruh mediasi dari pola konsumsi pada pengaruh variabel pendapatan terhadap kesejahteraan.

\section{Pengaruh jumlah anggota keluarga (X3) terhadap kesejahteraan melalui pola konsumsi (Z)}

Pengaruh langsung variabel jumlah anggota keluarga kesejahteraan (P3) adalah 0,148 kemudian untuk pengaruh tidak langsung variabel jumlah anggota keluarga terhadap kesejahteraan melalui pola konsumsi adalah $(P 6 \times P 7)=(0,572 \times 0,429)=$ 0,2453 . Sedangkan untuk total pengaruh langsung dan tidak langsung adalah P3 + 
$(\mathrm{P} 6 \times \mathrm{P} 7)=-0,148+(0,572 \times 0,429)=0,3933$. Untuk mengetahui pengaruh mediasinya, digunakan sobel test sebagai berikut:

$$
\begin{aligned}
& \text { Sp6p7 }=\sqrt{ } 7^{2} S p 6^{2}+p 6^{2} S p 7^{2}+S p 6^{2} S p 7^{2} \\
& \text { Sp6p7 }=\sqrt{ }(0,429)^{2}(0,065)^{2}+(0,572)^{2}\left(0,135^{2}\right)+(0,065)^{2}(0,135)^{2} \\
& \text { Sp6p7 }=\sqrt{ } 0,00077+0,00596+0,00007 \\
& \text { Sp6p7 }=\sqrt{ } 0,00680 \\
& \text { Sp6p7 }=0,08246 \\
& \text { Berdasarkan Sp6p7 maka dapat dihitung tstatistik dengan } \\
& \text { rumus sebagai berikut: } \\
& t=P 6 P 7: \text { Sp6p7 } \\
& =0,245388: 0,08246 \\
& =2,97584
\end{aligned}
$$

Dari nilai t hitung diatas yaitu sebesar 2,97584 lebih besar dari t tabel 1,66055 dengan signifikansi $5 \%$. Maka dapat diambil kesimpulan bahwa ada pengaruh mediasi dari pola konsumsi pada pengaruh jumlah anggota keluarga terhadap kesejahteraan.

\subsection{Pembahasan}

\section{Pengaruh religiusitas terhadap kesejahteraan}

Berdasarkan hasil uji $\mathrm{t}$ yang telah dilakukan sebelumnya, variabel religiusitas menunjukan nilai signifikansi sebesar 0,000 $<0,05$. Dengan demikian dapat disimpulkan bahwa religiusitas memiliki pengaruh yang positif dan signifikan terhadap kesejahteraan. Maka hipotesis pertama $(\mathrm{H} 1)$ yakni religiusitas berpengaruh positif dan signifikan terhadap kesejahteraan diterima.

Seperti hubungan religiusitas dengan kesejahteraan yang telah dijelaskan dalam Al-Quran Surat Al-Araf ayat 96 yang menjelaskan mengenai limpahan berkah yang akan Allah berikan ketika kaum dalam suatu negara memiliki keimanan dan ketaqwaan dan sebaliknya jika manusia melakukan larangan Allah maka yang akan didapat hanyalah siksaan kelak. Hasil penelitian variable ini sejalan dengan penelitian tentang analisis pengaruh religiusitas terhadap kesejahteraan falah oleh (Zakariya, 2018) yang menyatakan bahwa religiusitas memiliki pengaruh yang positif dan signifikan terhadap kesejahteraan. Sama halnya dengan Nurul Fatmawati pada 2017 yang menyatakan bahwa religiusitas berhubungan positif signifikan dengan kesejahteraan pada masyarakat.

\section{Pengaruh pendapatan terhadap kesejahteraan}

Berdasarkan hasil uji t yang telah dilakukan sebelumnya, variabel pendapatan menunjukan nilai signifikansi sebesar 0,686 $>0,05$. Dengan demikian dapat diketahui bahwa pendapatan tidak berpengaruh terhadap kesejahteraan. Maka hipotesis kedua $(\mathrm{H} 2)$ yakni pendapatan berpengaruh positif dan signifikan terhadap kesejahteraan ditolak. 
Tidak berpengaruhnya pendapatan terhadap kesejahteraan dapat disebabkan karena tingkat pendapatan yang masih rendah sedangkan kebutuhan masyarakat masih tinggi seperti penelitian yang dilakukan oleh Randy Rizki Syofiandi, Rudi Hilman, dan Susni Hewanti (2016). Dengan demikian, pendapatan yang diperoleh hanya difokuskan pada kebutuhan konsumsi dan kurang dapat mencukupi kebutuhan lainnya sehingga kesejahteraan tergolong rendah (Rizki Syofiandi, Hilmanto, \& Herwanti, 2016).

Konsep kesejahteraan memilki beberapa factor yakni system nilai alami, kekuatan ekonomi sector riil, pemenuhan kebutuhan dasar dan system distribusi, serta keamanan dan ketertiban sosial. Seseorang dikatakan sejahtera ketika factor tersebut terpenuhi (Beik \& Arsyianti, 2016). Pendapatan yang diterima seseorang mungkin saja tidak dapat memenuhi salah satu factor tersebut sehingga tidak mencapai kesejahteraan. Seperti penelitian Adam Sugiharto, Hartoyo, dan Istiqlaliyah Muflikhati (2016) menjelaskan bahwa ploting pendapatan seseorang tidak berpengaruh terhadap kesejahteraan. (Sugiharto, Hartoyo, \& Muflikhati, 2016)

\section{Pengaruh jumlah anggota keluarga terhadap kesejahteraan}

Berdasarkan hasil uji t yang telah dilakukan sebelumnya, variabel jumlah anggota keluarga menunjukan nilai signifikansi sebesar 0,202 >0,05. Dengan demikian dapat diketahui bahwa jumlah anggota keluarga tidak berpengaruh terhadap kesejahteraan. Maka hipotesis ketiga $(\mathrm{H} 3)$ yakni jumlah anggota keluarga berpengaruh positif dan signifikan terhadap kesejahteraan ditolak.

Berdasarkan frekuensi jumlah anggota keluarga responden didominasi oleh jumlah anggota keluarga sebanyak 3-4 orang dan rata-rata responden berusia 20 hingga 25 tahun yang merupakan keluarga kecil ataupun kelaurga baru. Menurut pengakuan beberapa responden dalam satu keluarga tersebut hanya terdapat satu orang pekerja. (Syafitri, 2019) menjelaskan bahwa salah satu factor yang dapat digunakan untuk mengukur kesejahteraan ialah jumlah pekerja dalam keluarga. Semakin banyak anggota keluarga akan meningkatkan pendapatan ketika terdapat banyak pekerja pula dalam ruam $h$ tangga tersebut.

Pada kenyataannya, anggota keluarga yang ada masih berupa anak-anak ataupun orang tua yang bukana ngkatan kerja sehingga tidak mampu menambah penghasilan untuk meningkatkan kesejahteraan. Dengan demikian ada sedikit atau banyaknya jumlah anggota keluarga dapat saja tidak berpengaruh kepada kesejahteraan dikarenakan factor pemenuhan kebutuhan masih saja sulit terpenuhi. Apalagi ketika jumlah anggota yang ada tidak diimbangi dengan pendapatan yang cukup maka banyak atau tidaknya tanggungan keluarga tidak menjadi pengaruh besar terhadap kesejahteraan seperti penelitian yang dilakukan oleh Purwanto \& Taftazani pada tahun 2018).

\section{Pengaruh pola konsumsi terhadap kesejahteraan}

Berdasarkan hasil uji t yang telah dilakukan sebelumnya, variabel jumlah anggota keluarga menunjukan nilai signifikansi sebesar 0,002<0,05. Dengan demikian dapat diketahui pola konsumsi berpengaruh terhadap kesejahteraan. Maka hipotesis 
keempat $(\mathrm{H} 4)$ yakni pola konsumsi berpengaruh positif dan signifikan terhadap kesejahteraan diterima. Sejalan dengan Q.S Al-Quraisy ayat 3-4 yangkurang lebih bermakna bahwa hendaknya setiap manusia menyembah hanya kepada Sang Pencipta yang memiliki dunia dan segala isinya. Yaitu Allah yang telah memberikan rizki kepada manusia sehingga terhindar dari kelaparan, memberi rasa aman dan terhindar dari kecemasan. Kegiatan yang dapat mendorong hal tersebut salah satunya adalah kegiatan konsumsi (Zakariya, 2018).

Hasil ini relevan dengan penelitian oleh (Amanaturrohim, 2015) menunjukkan bahwa pendapatan dan konsumsi rumah tangga akan berpengaruh terhadap kesejahteraan secara positif baik parsial maupun simultan. Hal tersebut sejalan dengan penelitian (Rahmasari, 2017) yang menyatakan bahwa pola konsumsi berpengaruh positif dan signifikan terhadap kesejahteran.

\section{Pengaruh religiusitas terhadap pola konsumsi}

Berdasarkan hasil uji $\mathrm{t}$ yang telah dilakukan sebelumnya, variabel religiusitas menunjukan nilai signifikansi sebesar 0,517>0,05. Dengan demikian dapat diketahui religiusitas tidak berpengaruh terhadap pola konsumsi. Maka hipotesis kelima (H5) yakni religiusitas berpengaruh positif dan signifikan terhadap pola konsumsi ditolak.

Pola konsumsi dalam suatu rumah tangga dalam penelitian ini tidak dipengaruhi oleh relligiusitas. Hal tersebut bisa saja terjadi dikarenakan tidak semua orang yang memiliki nilai religiusitas tinggi juga memiliki pendapatan dan jumlah anggota keluarga yang banyak. jika dilihat dalam hasil jawaban responden dalam penelitian ini dapt dilihat nilai relgiusitas yang cenderung tinggi namun diketahui bahwa tingkat pendapatan masyarakat didominasi bernilai kurang dari Rp 2.300.000 yang artinya masih di bawah angka upah minimum regional. Dalam penelitian Siska Alfiati pada tahun 2018 dikemukakan bahwa pola konsumsi dapat dipengaruhi beberapa factor berupa jumlah pendapatan dan jumlah anggota keluarga dalam suatu rumah tangga (Alfiati, 2018).

\section{Pengaruh pendapatan terhadap pola konsumsi}

Berdasarkan hasil uji t yang telah dilakukan sebelumnya, variabel pendapatan menunjukan nilai signifikansi sebesar 0,065 > 0,05. Dengan demikian dapat diketahui pendapatan tidak berpengaruh terhadap pola konsumsi. Maka hipotesis keenam (H6) yakni pendapatan berpengaruh positif dan signifikan terhadap pola konsumsi ditolak.

Pendapatan dalam penelitian ini tidak cukup untuk mempengaruhi pola konsumsi pada masyarakat Muslim Kabupaten Semarang. Sejatinya pendapatan adalah salah satu hal yang dapat mempengaruhi pola konsumsi masyarakat namun berbeda dengan hasil penelitian ini karena nyatanya hal itu tidak terjadi. Beberapa factor lain yang mungkin saja mengakibatkan pendapatan tidak memiliki pengaruh terhadap pola konsumsi masyarakat. Salah satunya adalah pola konsumsi yang dijalankan tidak sesuai dengan pendapatan yang ada.

Pola konsumsi dalam penelitian ini dibagi menjadi konsumsi makanan dan non makanan. Dengan dominasi pendapatan rendah sedangkan harga bahan pokok 
terus meningkat mengakibatkan masarakat hanya terfokus pada konsumsi makanan. Sehingga ketika hanya makanan yang terpenuhi kebutuhan non makanan menjadi terbengkalai. Maka dari itu besar kecilnya pendapatan yang ada ketika harga bahan yang ada mengikuti naik maka meningkatnya pendapatan tidak akan meningkatkan pola konsumsi begitu pula sebaliknya.

\section{Pengaruh jumlah anggota keluarga terhadap pola konsumsi}

Berdasarkan hasil uji $\mathrm{t}$ yang telah dilakukan sebelumnya, variabel religiusitas menunjukan nilai signifikansi sebesar 0,000 <0,05. Dengan demikian dapat diketahui jumlah anggota keluarga berpengaruh terhadap pola konsumsi. Maka hipotesis ketujuh ( $\mathrm{H} 7)$ yakni jumlah anggota keluarga berpengaruh positif dan signifikan terhadap pola konsumsi diterima.

Bagaimana kegiatan konsumsi dalam keluarga sangat ditentukan oleh jumlah anggota keluarga. Hal tersebut terjadi dakarenakan anggota keluarga menjadi pelaku ekonomi. Banyaknya pelaku ekonomi tersebut menentukan sikap dan tindakan pada kelaurga dalam melakukan aktivitas ekonomi. Semakin besar jumlah keluarga maka pembagian dalam alokasi pendapatan akan cenderung semakin kecil bagi tiap anggota kelaurga begitu pula sebaliknya (Fielnanda \& Sahara, 2018).

Sejalan dengan penelitan yang dilakukan oleh Eka Vidiawan dan Ni Made Trisnawati pada tahun 2015 mengenai pengaruh jumlah anggota kelaurga terhadap pola konsumsi keluarga yang menghasilkan kesimpulan bahwa jumlah anggota keluarga berpengaruh secara signifikan terhadap pola konsumsi. Begitupun pada penelitian Refky Fielnanda dan Nur sahara pada tahun 2018 yang mengemukakan bahwa jumlah orang dalam keluarga mampu memberi pengaruh yang positif dan besar pengaruhnya terhadap pola konsumsi yang dijalankan.

\section{Pengaruh religiusitas terhadap kesejahteraan masyarakat melalui pola konsumsi}

Berdasarkan hasil analisis jalur atau path analysis, diketahui nilai $t$ hitung yaitu sebesar 0,667 lebih besar dari t tabel senilai 1,66055 dengan signifikansi $5 \%$ atau 0,05 . Sehingga dapat disimpulkan bahwa terdapat pengaruh mediasi dari pola konsumsi pada variabel religiusitas terhadap kesejahteraan.

Pada hubungan ini dapat dilihat bahwa pola konsumsi mampu menjadi mediator dalam religiusitas mempengaruhi kesejahteraan pada masyarakat Muslim Kabupaten Semarang. Hal ini sejalan dengan penelitian (Zakariya, 2018) yang pola konsumsi mempunyai kekuatan untuk memediasi berpengaruhnya religiusitas seseorang terhadap kesejahteraannya. Dengan demikian dapat diketahui bahwa tingkat religiusiitas masyarakat Muslim di Kabupaten Semarang cukup tinggi yang mana mampu memberi pengaruh kepada kesejahteraan yang dapat dilihat melalui pola konsumsi yang dilakukan sehingga memiliki akibat yang searah.

Pengaruh pendapatan terhadap kesejahteraan masyarakat melalui pola konsumsi 
Berdasarkan hasil analisis jalur atau path analysis, diketahui nilai $\mathrm{t}$ hitung yaitu sebesar 0,44983 lebih besar dari t tabel 1,66055 dengan signifikansi 5\%. Maka dapat diambil kesimpulan bahwa ada pengaruh mediasi dari pola konsumsi pada pengaruh variabel pendapatan terhadap kesejahteraan.

Kesejahteraan masyarakat Muslim di Kabupaten Semarang dipengaruhi oleh pendapatan melalui pola konsumsi sebagai variable mediasi. Tingkat pendapatan yang mampu berpengaruh terhadap pola konsumsi sesuai dengan penelitian (Soesatyo \& Indrianawati, 2015) dan (Haqiqi, Subroto, Surabaya, Tangga, \& Keluarga, 2021) yang menyatakan bahwa pendapatan memiliki kemampuan untuk memberi pengaruh yang besar dan searah kepada bagaimana orang dalam keluarga mengelola konsumsinya. Pola konsumsi rumah tangga yang telah dipengaruhi oleh pendapatan tersebut selanjutnya dapat berpengaruh terhadap kesejahteraan. Sejalan dengan penelitian yang dilakukan oleh (Rahmasari, 2017) yang menyatakan bahwa pola konsumsi memiliki kemampuan memengaruhi kesejahteraan. Dengan demikian terdapat hubungan antara pendapatan, pola konsumsi dan kesejahteraan dimana pola konsumsi mampu memediasi pengaruh pendapatan terhadap kesejahteraan pada masyarakat Muslim Kabupaten Semarang.

\section{Pengaruh jumlah anggota keluarga terhadap kesejahteraan masyarakat melalui pola konsumsi}

Berdasarkan hasil analisis jalur atau path analysis, diketahui nilai $t$ hitung yaitu sebesar 2,97584 lebih besar dari t tabel 1,66055 dengan signifikansi 5\%. Maka dapat diambil kesimpulan bahwa ada pengaruh mediasi dari pola konsumsi pada pengaruh jumlah anggota keluarga terhadap kesejahteraan.

Dalam penelitian ini diketahui bahwa pola konsumsi memiliki kemampuan untuk memediasi pengaruh jumlah anggota keluarga terhadap kesejahteraan masyarakat Muslim di Kabupaten Semarang. Jika dilihat dalam pengaruh langsung, jumlah anggota keluarga tidak memiliki pengaruh terhadap kesejahteraan. Namun jumlah anggota keluarga nyatanya memiliki pengaruh yang positif dan signifikan terhadap pola konsumsi dikarenakan memiliki nilai significan sebesar 0,000 yang kurang dari 0,05 . Dengan pengaruh tersebut, pola konsumsi mampu memberi pengaruh pula terhadap kesejahteraan baik dalam penelitian ini maupun penelitian oleh (Hanum \& Safuridar, 2018) yang menyatakan bahwa pola konsumsi berpengaruh positif dan signifikan terhadap kesejahteraan.

\section{Kesimpulan}

Berdasarkan pada hasil uji tyang telah dilakukan, menunjukkan bahwa secara positif dan signifikan religiusitas dan pola konsumsi memberi pengaruh terhadap kesejahteraan masyarakat. Sedangkan pendapatan dan jumlah anggota keluarga tidak memberi pengaruh terhadap kesejahteraan mayarakat. Uji $F$ menunjukkan bahwa variabel religiusitas, pendapatan, jumlah anggota keluarga, dan pola konsumsi secara simultan berpengaruh positif dan sifnifikan terhadap kesejahteraan masyarakat. Melalui analisis jalur, dapat dikemukakan bahwa pola konsumsi mampu 
memediasi pengaruh religiusitas, pendapatan, jumlah anggota keluarga terhadap kesejahteraan masyarakat Muslim di Kabupaten Semarang.

\section{Ucapan Terimakasih}

Terimakasih kepada seluruh pendukung dalam penyusunan naskah penelitian ini Seluruh responden sehingga data dapat terkumpul dan dapat dilakukan penelitian ini. Kedua orang tua yang memberi doa serta semangat sehingga tanpa hal tersebut penulisan naskahn ini mungkin akan sulit terwujud.

\section{Referensi}

Alfiati, S. (2018). Analisis FaktorFaktor yang Mempenganuhi Pola Konsumsi Rumah Tangga. Journal of Economics, Business and Accounting (COSTING), 2(1), 7683.

Amanaturrohim, H. (2015). Pengaruh pendapatan dan konsumsi rumah tangga terhadap kesejahteraan keluarga petani penggarap kopi di kecamatan Candiroto kabupaten Temanggung. (Skripsi). In Universitas Negeri Semarang, Semarang.

Bawono, A. (2006). Multivariate analysis dengan SPSS. Salatiga: STAIN Salatiga Press.

Bawono, A., \& Shina, A. F. I. (2018). Ekonomika Terapan untuk Ekonomi dan Bisnis Islam. Salatiga: LP2M IAIN Salatiga.

Beik, I. S., \& Arsyianti, L. D. (2016). Ekonomi Pembangunan Syariah. Jakarta: PT Grafindo Persada.

Fielnanda, R., \& Sahara, N. (2018). Pola Konsumsi Rumah Tangga Nelayan Di Desa Mendahara Ilir Kec. Mendahara Kabupaten Tanjung Jabung Timur. ILTIZAM Journal of Sharia Economic Research, 2(2), 89. https://doi.org/10.30631/iltizam.v2i2.171

Ghozali, I. (2016). Aplikasi Analisis Multivariate Dengan Program IBM SPSS 23 Edisi 8 (8th ed.). Semarang: Badan Peneliti Universitas Diponegoro.

Hanum, N. (2017). Analisis Pengaruh Pendapatan Terhadap Perilaku Konsumsi Mahasiswa Universitas Samudra di Kota Langsa. Jurnal Samudra Ekonomika, 1(2), 107-116.

Hanum, N., \& Safuridar, S. (2018). Analisis Kondisi Sosial Ekonomi Keluarga terhadap Kesejahteraan Keluarga di Gampong Karang Anyar Kota Langsa. Jurnal Samudra Ekonomi Dan Bisnis, 9(1), 42-49. https://doi.org/10.33059/jseb.v9i1.460

Haqiqi, A. H., Subroto, W. T., Surabaya, U. N., Tangga, K. R., \& Keluarga, K. (2021). Pengaruh pendapatan dan konsumsi rumah tangga terhadap kesejahteraan keluarga penerima manfaat bantuan sosial pkh. Jurnal Education and Development, 9(2), 484-493.

Ma'zumi. (2017). Pengaruh Religiusitas terhadap Perilaku Ekonomi Masyarakat Pasar Tradisional. Al-Qalam, 34, 277-299.

Nuriyanto, M. Z., Abidin, Z., Syahfiar, A., Firmansyah, F. A., Rianto, W. J. F., Prasetyono, I., ... Kurnianto, F. A. (2019). Analisis Pola Konsumsi Dan Gaya 
Hidup Mahasiswa Pendidikan Geografi Universitas Jember Angkatan 2018. Majalah Pembelajaran Geografi, Vol 2, No.(2).

Pratama, A. A. N., \& Yudiana, F. E. (2020). Perilaku konsumen muslim, religiusitas dan perilaku hijrah (D. M. M.Ag, ed.). Salatiga: Lembaga Penelitian dan Pengabdian kepada Masyarakat (LPM2M) IAIAN Salatiga.

Purwanto, A., \& Taftazani, B. M. (2018). Pengaruh Jumlah Tanggungan Terhadap Tingkat Kesejahteraan Ekonomi Keluarga Pekerja K3L Universitas Padjadjaran. Focus: Jurnal Pekerjaan Sosial, 33. https://doi.org/10.24198/focus.v1i2.18255

Rahmasari, L. (2017). Analisis Pola Konsumsi, Kewirausahaan dan Pengaruhnya terhadap Kesejahteraan Nelayan. Jurnal Saintek Maritim, 3.

Rizki Syofiandi, R., Hilmanto, R., \& Herwanti, S. (2016). Analisis Pendapatan Dan Kesejahteraan Petani Agroforestri Di Kelurahan Sumber Agung Kecamatan Kemiling Kota Bandar Lampung. Jurnal Sylva Lestari, 4(2), 17. https://doi.org/10.23960/js|2417-26

Soesatyo, Y., \& Indrianawati, E. (2015). Pengaruh Tingkat Pendapatan dan Pengetahuan Ekonomi Terhadap Tingkat Konsumsi Mahasiswa Program Pascasarjana Universitas Negeri Surabaya. Jurnal Ekonomi Pendidikan Dan Kewirausahaan, Vol.3 No.1,214-226.

Sugiharto, A., Hartoyo, H., \& Muflikhati, I. (2016). Strategi Nafkah dan Kesejahteraan Keluarga Pada Keluarga Petani Tadah Hujan. Jurnal Ilmu Keluarga Dan Konsumen, 9(1), 33-42. https://doi.org/10.24156/jikk.2016.9.1.33

Syafitri, N. (2019). Penganuh Pendapatan, Pendidikan, dan Jumlah Anggota Keluarga Terhadap Tingkat Kesejahteraan Keluarga di Kecamatan Medan Belawan.

Vidiawan, E., \& Tisnawati, N. M. (2015). Analisis Pengaruh Pendapatan, Jumla Anggota Keluarga dan Pendidikan Terhadap Jumlah Konsumsi Rumah Tangga Miskin di Desa Batu Kandik Kecamatan Nusa Penida Kabupaten Klungkung. EJurnal EP Unud, 4(4), 243-257.

Zakariya, A. R. (2018). Analisis Pengaruh Religiusitas terhadap Kesejahteraan dalam Konsep Islam Falah dengan Pola Konsumsi Rumah Tangga Sebagai Variabel Mediasi. UIN Maulana Malik Ibrahim Malang. 